\title{
Test Plan for Monitoring Cooling Coils in a Laboratory Setting
}

\author{
Topical Report
}

Don B. Shirey, III

April 2002

DOE/NETL Project No. DE-FC26-01NT41253

Understanding the Dehumidification Performance of Air-Conditioning Equipment at Part-Load Conditions 


\section{DISCLAIMER}

This report was prepared as an account of work sponsored by an agency of the United States Government. Neither the United States Government nor any agency thereof, nor any of their employees, makes any warranty, express or implied, or assumes any legal liability or responsibility for the accuracy, completeness, or usefulness of any information, apparatus, product, or process disclosed, or represents that its use would not infringe privately owned rights. Reference herein to any specific commercial product, process, or service by trade name, trademark, manufacturer, or otherwise does not necessarily constitute or imply its endorsement, recommendation, or favoring by the United States Government or any agency thereof. The views and opinions of authors expressed herein do not necessarily state or reflect those of the United States Government or any agency thereof. 


\begin{abstract}
The objective of this research project is to understand and quantify the moisture removal performance of cooling coils at part-load conditions. The project will include a comprehensive literature review, detailed measurement of cooling coil performance in a laboratory facility, monitoring cooling systems at several field test sites, and development/validation of engineering models that can be used in energy calculations and building simulations.

This document contains the detailed test plan for monitoring cooling coil performance in a laboratory setting. Detailed measurements will be taken on up to 10 direct expansion (DX) and chilled water cooling coils in various configurations to understand the impact of coil geometry and operating conditions on transient moisture condensation and evaporation.
\end{abstract}




\section{TABLE OF CONTENTS}

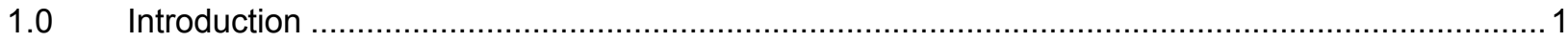

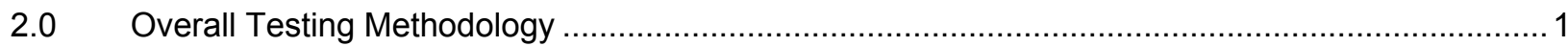

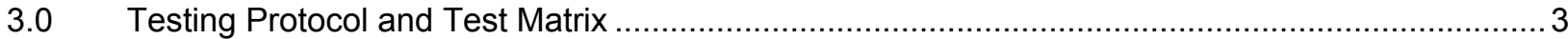

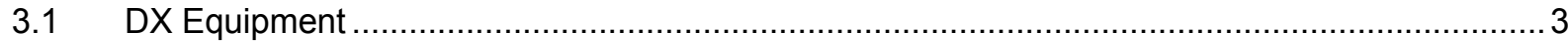

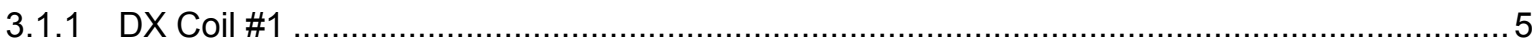

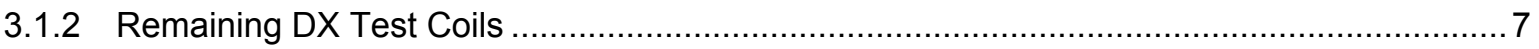

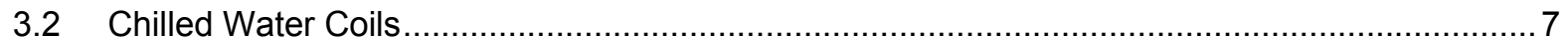

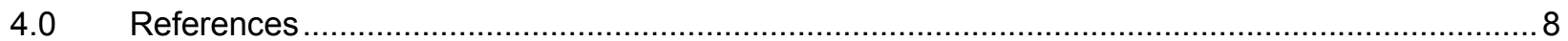




\title{
Test Plan for Monitoring Cooling Coils in a Laboratory Setting
}

\author{
DOE/NETL Project No. DE-FC26-01NT41253 \\ Understanding the Dehumidification Performance of Air-Conditioning Equipment at Part-Load Conditions \\ Don B. Shirey, III \\ University of Central Florida / Florida Solar Energy Center \\ April 4, 2002
}

\subsection{Introduction}

The objective of this research project is to understand and quantify the moisture removal performance of cooling coils at part-load conditions. The project will include a comprehensive literature review, detailed measurement of cooling coil performance in a laboratory facility, monitoring cooling systems at several field test sites, and development/validation of engineering models that can be used in energy calculations and building simulations. This document contains the detailed test plan for monitoring cooling coil performance in a laboratory setting.

As outlined in the contract's "Statement of Project Objectives", the Florida Solar Energy Center (FSEC) will take detailed measurements on up to 10 direct expansion (DX) and chilled water cooling coils in various configurations to understand the impact of coil geometry and operating conditions on transient moisture condensation and evaporation. One or two of the tested coils will be similar to those used in airconditioning equipment monitored during the field-testing portion of this project, allowing for verification of expected links between observed field performance and the detailed laboratory test results. The lab testing data will be used to determine various performance parameters, including off-cycle moisture evaporation rates and the moisture holding capacity of the cooling coil surfaces at various operating conditions. During lab testing, FSEC will also evaluate the effect of lower cost measurement techniques that can be utilized during the upcoming field-testing portion of the project, which is scheduled to begin in late-Spring 2002.

A contract modification is currently being processed to expand the project scope of work, including a modest expansion to the project's laboratory testing task. Lab testing will be expanded to include one additional test on the first laboratory test coil. Since the contract modification should be executed shortly, we will include the additional test in this test plan document.

\subsection{Overall Testing Methodology}

FSEC will utilize an existing laboratory facility to perform the necessary testing. The facility contains two psychrometric chambers that can be used to maintain various air conditions (dry-bulb temperature and humidity levels) while testing the performance of air-conditioning equipment. Both chambers will be utilized when testing the direct expansion coils (indoor coil in one chamber and the air-cooled condensing unit in the adjacent chamber), while only one chamber will be required for testing chilled water coils. A schematic of the psychrometric chambers and DX coil testing apparatus is shown in Figure 1. Since November 2001, FSEC personnel have been working to refurbish the test facility, calibrate instrumentation, and establish a mechanism for collecting and storing the large volume of data that will be collected from each coil test. These activities are nearly completed, and we anticipate that the facility will be ready for testing by mid-April 2002.

Lab testing will focus on direct expansion cooling coils since they are used in virtually all residential cooling applications, and cover a very large portion of commercial building cooling applications as well. Chilled water cooling coils will also be tested, but these tend to be used in larger commercial/industrial cooling systems. We anticipate testing 6 to $8 \mathrm{DX}$ cooling coils and 1 or 2 chilled water coils in the lab as part of this project. The lab is currently configured for testing DX cooling coils; therefore the 6 to $8 \mathrm{DX}$ 
(I)

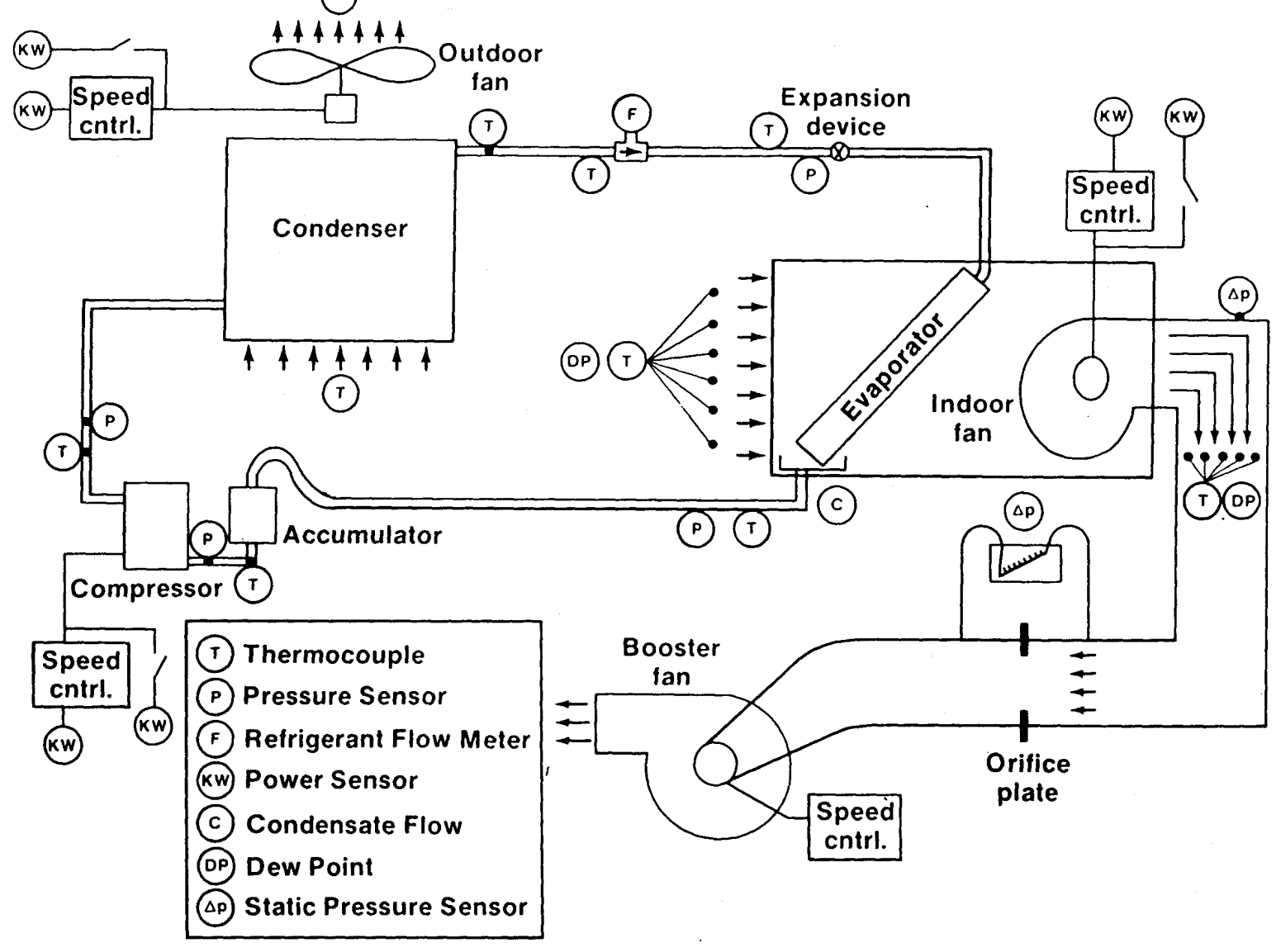

Figure 1. Schematic of Psychrometric Chambers/Coil Testing Apparatus at FSEC

coils will be tested first followed by the chilled water coils. Some lab modifications will need to be made after DX coil testing before the chilled water coils can be evaluated.

As explained previously, the ultimate goal of this project is to develop and validate mathematical models that can be used in energy calculations and building simulations. A model for one particular case - a DX cooling coil that cycles on and off while the supply air fan runs continuously - was previously developed and verified based on a limited data set (Henderson and Rengarajan 1996; Henderson 1998). We plan to collect additional data during this project to validate this existing model, as well as extend the modeling approach to different configurations and coil types.

The existing mathematical model requires two key input parameters that are not readily available from manufacturer's published data and will be obtained from coil testing during this project: 1) the moisture holding capacity of the cooling coil, and 2) the initial rate at which moisture is evaporated from the cooling coil when the compressor is turned off. The moisture removal performance of the cooling coils will be monitored during the lab tests using high-precision instruments with fast response times (i.e., calibrated tipping buckets and chilled mirror hygrometers with sampling pumps) to determine these key parameters.

Each coil will be subjected to a battery of tests as described later in this plan. Because of the significant effort required to switch test coils, the monitored data for each cooling coil will be evaluated once the battery of tests is completed to determine if the requisite data have been collected or if additional testing is required. 


\section{0}

Testing Protocol and Test Matrix

We plan to perform a wide array of tests on the first test coil to determine which parameters affect dehumidification performance at part-load conditions. Once the specific parameters of interest and requisite tests have been identified, we expect that the test matrix for the remaining coils will be much smaller.

\subsection{Equipment}

As explained previously, 6 to $8 \mathrm{DX}$ cooling coils will be tested as part of this project. The test coils will be installed along with an existing 3-ton variable speed, air-cooled condensing unit located in the laboratory facility. The variable capacity capability will allow numerous steady-state operating conditions to be achieved with the use of a single condensing unit.

During the literature review portion of this project, an analysis was completed of evaporator coil characteristics compiled from published specifications for more than 500 air-conditioning products from four major U.S. equipment manufacturers. This information will be used to guide the selection of coils for detailed laboratory testing.

Figure 2 shows the breakdown of collected information in terms of number of evaporator coil rows. Clearly 3-row evaporator coils are the most common $(60 \%$ of the coils surveyed), with 2-row and 4-row coils being less common (each representing approximately $20 \%$ of the coils surveyed). Given this information, we plan to test a similar cross section of DX coils in the laboratory (four or five 3-row coils, and one or two each of 2-row and 4-row coils). Three 3-row DX coils will be tested first, followed by a single 4-row coil and a single 2-row coil. After the testing of these five coils is completed, the test results will be reviewed before selecting the remaining DX coils to be tested. Besides the number of coil rows, fin spacing and coil face area ( $\mathrm{ft}^{2}$ per nominal ton of cooling) are key parameters that affect the moisture holding capacity of the coil, and this information (collected as part of the AC equipment survey) will be considered when selecting the specific evaporator coils to be tested.

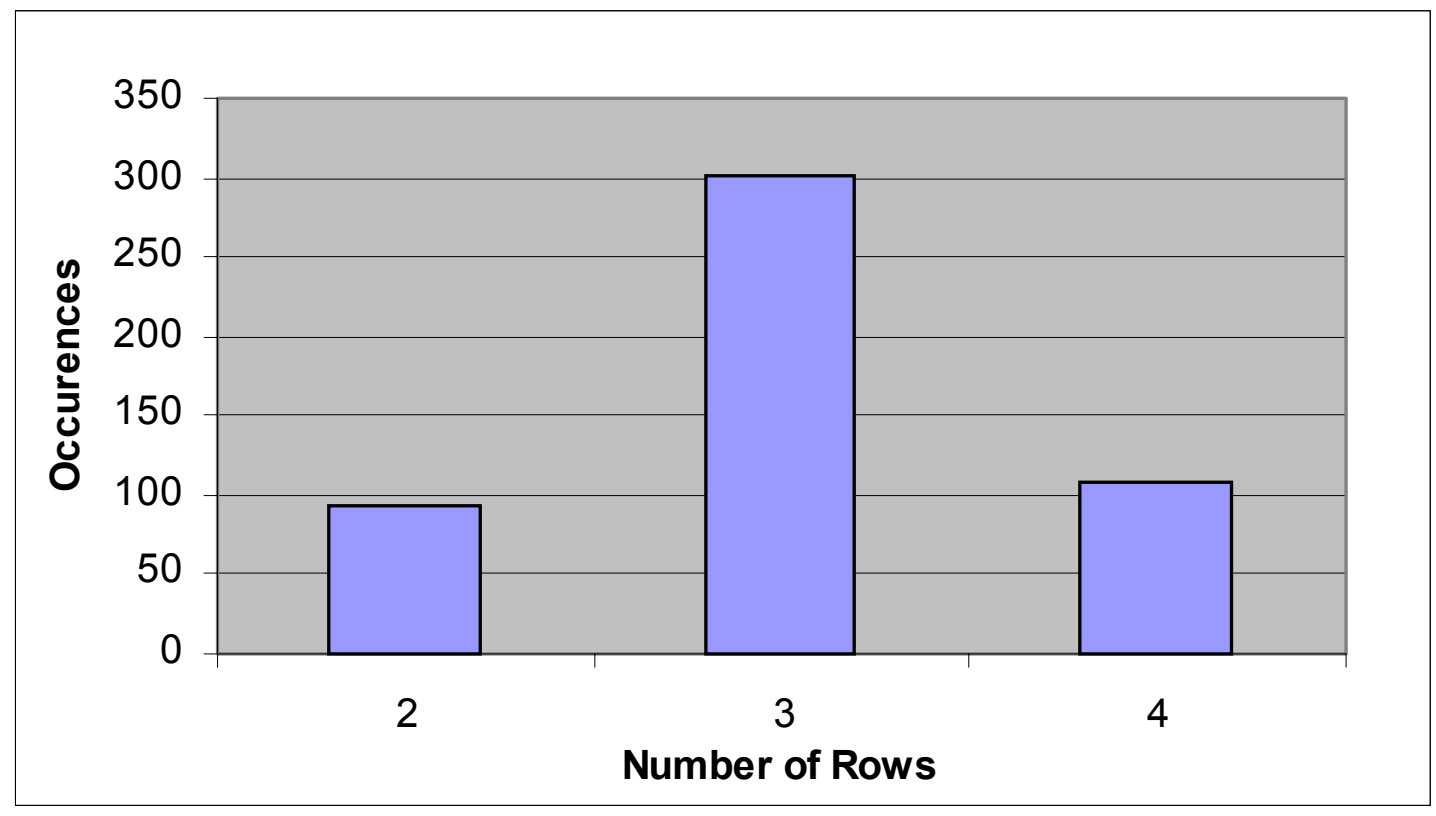

Figure 2. Breakdown of Available Evaporator Coils (Number of Coil Rows) 
Specific coil selection will be based on the following criteria:

- $\quad$ test a representative sample of evaporator coils based the survey of more than 500 airconditioning products completed as part of the literature review portion of this project, and test one or two coils similar to those used in air-conditioning equipment monitored during the field-testing portion of this project

The first coil to be tested will be an existing 3-row evaporator contained in an air-handling unit. While manufactured in the late 1980s, the characteristics of this coil match quite well with currently-available evaporator coils as seen from the AC equipment survey performed for this project. A limited amount of data related to the dehumidification performance of this coil at part-load conditions has already been obtained from earlier tests performed at FSEC. This existing performance data will be used to help verify that the test chambers, instrumentation and this specific DX system are operating properly for the purposes of this project.

Table 1 contains the list of parameters that will be monitored during each DX coil test. A total of 17 individual measurements will be made, including the dry-bulb and dew point temperatures of air entering and leaving the cooling coil, air volume flow rate across the coil and condensate removal rate. For the dry-bulb temperature of air entering and leaving the coil, a grid of type-T thermocouples will be installed perpendicular to the air stream and the average of the thermocouple readings will be stored by the datalogger as the air state point. In a similar fashion, the air dew point temperature will measured by pulling a representative air sample from multiple points in the air stream using a small-diameter copper tubing grid installed perpendicular to the direction of air flow (see Figure 1 for locations).

Because of the quick changes that occur when the cooling coil is activated or deactivated, we plan to collect all 17 data points once every 15 seconds. This large amount of data (more than 4000 data points per hour of testing) will be transferred to FSEC's mainframe computer "real time" (i.e., every scan will be transferred as soon as it is collected by the laboratory datalogger). Once on the mainframe computer, existing software screens, compresses and stores the data for later retrieval and analysis. The data are copied to other media on a daily basis for backup purposes.

Table 1. Data Points for Lab Monitoring of DX Coils

\begin{tabular}{|l|l|}
\hline Description & Instrumentation \\
\hline Coil entering air dew point temperature & Chilled mirror hygrometer with sampling pump \\
\hline Coil entering air dry-bulb temperature & Type-T thermocouples \\
\hline Supply air dew point temperature & Chilled mirror hygrometer with sampling pump \\
\hline Supply air dry-bulb temperature & Type-T thermocouples \\
\hline Supply air fan power & Power transducer \\
\hline Air volume flow rate across coil & Calibrated orifice plate, pressure transducer \\
\hline Refrigerant pressure at coil outlet (compressor suction) & Pressure transducer \\
\hline Refrigerant temperature at coil outlet & Surface-mounted type-T thermocouple \\
\hline $\begin{array}{l}\text { Refrigerant pressure at expansion device inlet } \\
\text { (condenser outlet) }\end{array}$ & Pressure transducer \\
\hline Refrigerant temperature at expansion device inlet & Surface-mounted type-T thermocouple \\
\hline Liquid refrigerant flow rate & Turbine flow meter \\
\hline Compressor power & Power transducer \\
\hline Condensate removal rate & Calibrated rain gauge (tipping bucket) \\
\hline Evaporator coil tube temperature (3 places) & Surface-mounted type-T thermocouples \\
\hline Cooling coil air-side pressure drop & Pressure transducer \\
\hline
\end{tabular}




\subsubsection{Coil \#1}

A series of tests will be performed on the first DX coil as shown in Table 2. The tests will be performed in the order that they are listed. The collected data will be reviewed and analyzed along the way to determine if the proper data are being collected. Based on the analysis results, certain tests defined in Table 2 may be eliminated if earlier testing indicates that they are unnecessary, and additional tests may be added if it is determined they are needed for the model development/verification task.

Table 2. Test Matrix for the First DX Coil

\begin{tabular}{|c|c|c|}
\hline $\begin{array}{l}\text { Test } \\
\text { Number }\end{array}$ & Description & $\begin{array}{c}\text { Test } \\
\text { Sequence* }\end{array}$ \\
\hline 1 & $\begin{array}{l}\text { ARI Std. } 210 / 240-94 \text { Standard Rating Conditions "A" }(26.7 \mathrm{C} \text { [80F] db / } 19.4 \mathrm{C} \\
\text { [67F] wb indoor, } 35 \mathrm{C} \text { [95F] db outdoor), } 0.0537 \mathrm{~m}^{3} / \mathrm{s} \text { evaporator coil air flow per } \\
\text { nominal kW cooling capacity [ } 400 \mathrm{cfm} / \mathrm{ton}], 448 \mathrm{kPa}[65 \text { psig] coil outlet } \\
\text { pressure (compressor suction) }\end{array}$ & 1 \\
\hline 2 & Same as Test \#1, but with $517 \mathrm{kPa}$ [75 psig] coil outlet pressure & 1 \\
\hline 3 & Same as Test \#1, but with $483 \mathrm{kPa}$ [70 psig] coil outlet pressure & 1 \\
\hline $4-9$ & $\begin{array}{l}\text { Series of six tests at } 0.0537 \mathrm{~m}^{3} / \mathrm{s} \text { air flow per nominal } \mathrm{kW} \text { cooling capacity [400 } \\
\text { cfm/ton], compressor capacity and expansion device set per Test \#3, with six } \\
\text { different combinations of evaporator coil entering air conditions ( } 2 \mathrm{dry} \text {-bulb } \\
\text { temperatures, } 3 \text { wet-bulb temperatures): } 26.7 \mathrm{C} \mathrm{db} / 22.2 \mathrm{C} \mathrm{wb}[80 \mathrm{~F} / 72 \mathrm{~F}], 26.7 \mathrm{C} \\
\mathrm{db} / 19.4 \mathrm{C} \mathrm{wb}[80 \mathrm{~F} / 67 \mathrm{~F}], 26.7 \mathrm{C} \mathrm{db} / 16.7 \mathrm{C} \mathrm{wb}[80 \mathrm{~F} / 62 \mathrm{~F}], 23.9 \mathrm{C} \mathrm{db} / 20 \mathrm{C} \mathrm{wb} \\
\text { [75F/68F], 23.9C db / 17.2C wb [75F/63F], 23.9C db / 14.4C wb [75F/58F] }\end{array}$ & 1 \\
\hline $10-15$ & $\begin{array}{l}\text { Same as Tests } 4-9 \text {, except with } 0.0403 \mathrm{~m}^{3} / \mathrm{s} \text { air flow per nominal } \mathrm{kW} \text { cooling } \\
\text { capacity [300 cfm/ton] }\end{array}$ & 1 \\
\hline $16-21$ & $\begin{array}{l}\text { Same as Tests } 4-9 \text {, except with to } 0.0269 \mathrm{~m}^{3} / \mathrm{s} \text { air flow per nominal } \mathrm{kW} \\
\text { cooling capacity }[200 \mathrm{cfm} / \mathrm{ton}]\end{array}$ & 1 \\
\hline $22-24$ & $\begin{array}{l}\text { Same as Tests } 4-6 \text {, except with } 0.0605 \mathrm{~m}^{3} / \mathrm{s} \text { air flow per nominal } \mathrm{kW} \text { cooling } \\
\text { capacity [ } 450 \mathrm{cfm} / \text { ton] }\end{array}$ & 1 \\
\hline 25 & $\begin{array}{l}\text { Same as Test \#3, but reduce air flow to } 0.0269 \mathrm{~m}^{3} / \mathrm{s} \text { air flow per nominal } \mathrm{kW} \\
\text { cooling capacity [ } 200 \mathrm{cfm} / \mathrm{ton}] \text { when the cooling coil is off }\end{array}$ & 2 \\
\hline 26 & Same conditions as Test \#3, but using Test Sequence \#3 & 3 \\
\hline 27 & Same conditions as Test \#3, but using Test Sequence \#4 & 4 \\
\hline 28 & Same conditions as Test \#3, but using Test Sequence \#5 & 5 \\
\hline \multicolumn{3}{|c|}{$\begin{array}{l}\text { All tests will be run with air entering the outdoor (condensing) coil at } 35 \mathrm{C} \text { [95F]. } \\
\text { *Test Sequence \#1: run supply air fan with coil off to fully dry out the coil, run coil to reach steady-state } \\
\text { conditions, turn coil off while leaving supply air fan on until coil is fully dried out. } \\
\text { Test Sequence \#2: same as test sequence \#1, except reduce air flow rate to } 0.0269 \mathrm{~m} / \mathrm{s} \text { air flow per } \\
\text { nominal kW cooling capacity [200 cfm/ton] when the cooling coil is off. } \\
\text { Test Sequence \#3: run system with a } 50 \% \text { duty cycle (e.g., } 10 \text { minutes compressor on, } 10 \text { minutes } \\
\text { compressor off, } 10 \text { minutes compressor on, etc.) with the supply air fan running continuously. } \\
\text { Test Sequence \#4: same as test sequence \#3, except turn supply air fan off when cooling coil is off. } \\
\text { Test Sequence \#5: same as test sequence \#4, expect at a } 20 \% \text { duty cycle }(6.25 \text { minutes on, } 25 \text { minutes off) }\end{array}$} \\
\hline
\end{tabular}

Tests $1-3$

The first three tests involve operating the cooling coil at different coil temperatures (dictated by coil refrigerant pressure) while keeping all other variables the same. The coil inlet air conditions will be 26.7C [80F] dry-bulb and 19.4C [67F] wet-bulb, with air entering the air-cooled condenser at 35C [95F] (ARI Std. 210/240-94 Standard Rating Conditions "A"). The air volume flow rate will be set at $0.0537 \mathrm{~m}^{3} / \mathrm{s}$ per 
nominal $\mathrm{kW}$ cooling capacity [400 cfm/ton]. For the coil outlet pressure specified for each test, the compressor speed and expansion device (manual refrigerant isolation valve) will be adjusted to produce $4.4-6.7 \mathrm{C}[8-12 \mathrm{~F}]$ of coil superheat while assuring refrigerant subcooling at the expansion device (i.e., a full column of refrigerant liquid at the expansion device inlet).

For these first three tests, the test sequence will involve operating the supply air fan continuously with the compressor OFF for an extended period (30-60 minutes) to fully remove any coil moisture and bring the coil temperature to the inlet air dry-bulb temperature. Then the compressor will be turned on and operated until the sensible and latent output of the coil reaches steady-state conditions. Once steady state has been reached, the compressor will be turned off while the supply air fan remains on, and data will be collected until the supply air dry-bulb and dew point temperatures match the corresponding coil entering air temperatures.

The data collected from these first three tests will allow the determination of several key parameters required for the existing part-load dehumidification performance model (Henderson and Rengarajan 1996; Henderson 1998). In addition, the results will be analyzed to determine if the key model parameters change significantly with coil temperature. We anticipate that the coil temperature will have little impact on the key model input parameters.

\section{Tests $4-24$}

Tests 4 through 24 represent a matrix of tests that vary the coil inlet air conditions (temperature and humidity) and the air flow rate across the cooling coil. The expansion device and compressor speed settings established in Test 3 will be used for all of these tests.

\section{$\underline{\text { Test } 25}$}

Variable-speed indoor fans or even multi-tap, single-speed fan motors can be (and sometimes currently are) setup to run the fan continuously during the off-cycle but at $50 \%$ or less of the nominal flow rate. This lower airflow should result in less evaporation of moisture from the cooling coil into the supply air stream than if the air flow rate remained at full flow.

Test 25 will be similar to Test 3, but the coil air flow rate will be reduced from $0.0537 \mathrm{~m}^{3} / \mathrm{s}$ per $\mathrm{kW}$ to $0.0269 \mathrm{~m}^{3} / \mathrm{s}$ per $\mathrm{kW}$ [400 cfm/ton to $200 \mathrm{cfm} / \mathrm{ton}$ ] when the compressor is turned off. The data from this test will be compared to the data collected when the coil is operated at $0.0269 \mathrm{~m}^{3} / \mathrm{s} \mathrm{per} \mathrm{kW}$ [200 cfm/ton] during both the compressor on-cycle and off-cycle (Test 17). The test data will be analyzed to compare the off-cycle data collected during these two tests.

It is anticipated that off-cycle data collected during the two tests described above will be virtually identical. If not, UCF/FSEC will notify DOE of the findings and propose a different course of action to address this issue (e.g., expanded number of lab tests to be performed on each test coil).

\section{$\underline{\text { Test } 26}$}

Test 26 has the same operating conditions as Test 3, but the test sequence is different. For Test 26 , the compressor will be cycled on and off at a $50 \%$ duty cycle rate while the supply air fan runs continuously. As described previously, the data collected for Tests $3-24$ will allow key model input parameters to be determined for this particular cooling coil. With these input parameters, the existing part-load dehumidification performance model can be used to predict the coil performance at a $50 \%$ duty cycle, and the model prediction will be compared to the measured data from Test 26.

\section{$\underline{\text { Test } 27}$}

Test 27 has the same operating conditions as Test 3 , but the test sequence is different. In fact, Test 27 is just like Test 26, except the supply air fan is cycled on and off with the compressor. A limited amount of previous testing at FSEC has shown only a slight degradation in dehumidification performance when the fan and cooling coil cycle on and off together (Khattar et al. 1987). 


\section{$\underline{\text { Test } 28}$}

Test 28 is the same as Test 27 , except with a $20 \%$ duty cycle rate (versus $50 \%$ duty cycle rate for Test $27)$. Again, this test will help quantify the modest degradation in dehumidification performance when the fan and cooling coil cycle on and off together (i.e., AUTO fan).

\subsubsection{Remaining DX Test Coils}

Based on the test results for DX coil \#1, we will formulate the test matrix for the remaining DX coils to be tested in the laboratory. We anticipate that fewer tests will be performed on each of the remaining DX coils compared to the first DX test coil.

During the literature review portion of this project, one reference (Korte and Jacobi 1997) indicated that the amount of moisture retained on a cooling coil changes after several wet-dry cycles as factory-applied oil coatings wear off. Given this short-term transient behavior, we will operate the new DX test coils through 20 wet-dry cycles prior to the start of coil testing and data collection.

\subsection{Chilled Water Coils}

One or two chilled water coils will be tested in the lab as part of this project. Only one of the two laboratory psychrometric chambers will be required for testing these coils. Once the DX coil testing is completed, some laboratory modifications will be required to provide appropriate chilled water for chilled water coil testing. An existing air-cooled chiller is used to hold temperature conditions in the outdoor air psychrometric chamber containing the condensing unit for the DX coil testing. The chilled water piping system will be extended to serve the chilled water test coils, along with appropriate chilled water control valves.

Based on discussions with a local mechanical engineer, 4-row and 6-row chilled water coils are commonly used, with 4-row being the most common. Therefore, the first test coil will be 4-row and the second (if the project schedule and funding permit) will be a 6-row chilled water coil.

Table 3 contains the list of parameters that will be monitored during each chiller water coil test. A total of 14 individual measurements will be made, with many being the same parameters monitored during the DX coil testing. The dry-bulb and dew point temperatures of the air entering and leaving the cooling coil will be measured, as well as air volume flow rate across the coil and condensate removal rate. The method for measuring these air temperatures will be identical to the method used to measure them during the DX coil testing. The refrigerant pressures, temperatures and flow rate measured during the DX coil testing are replaced with chilled water temperatures entering and leaving the cooling coil as well as the water flow rate through the coil. As before, we plan to collect all data points once every 15 seconds, and immediately transfer the data to our mainframe computer for screening, compressing and storage for later retrieval and analysis.

The test matrix for the chilled water test coils will be formulated once the DX coil testing is completed. The DX coil testing will provide good insight into which tests will be important to run. We anticipate that the test matrix will be similar to that for the DX coil testing, with variations in coil inlet air conditions, coil temperature (inlet water temperature and water flow rate) and air flow rate across the cooling coil. 
Table 3. Data Points for Lab Monitoring of Chilled Water Coils

\begin{tabular}{|l|l|}
\hline Description & Instrumentation \\
\hline Coil Entering Air Dew Point Temperature & Chilled mirror hygrometer with sampling pump \\
\hline Coil Entering Air Dry-bulb temperature & Type-T thermocouples \\
\hline Supply Air Dew Point Temp & Chilled mirror hygrometer with sampling pump \\
\hline Supply Air Dry-bulb Temp & Type-T thermocouples \\
\hline Supply air fan power & Power transducer \\
\hline Air volume flow rate across coil & Calibrated orifice plate, pressure transducer \\
\hline Cooling coil water flow rate & Positive displacement flow meter \\
\hline Cooling coil water inlet temperature & Type-T thermocouple \\
\hline Cooling coil water outlet temperature & Type-T thermocouple \\
\hline Condensate removal rate & Calibrated rain gauge (tipping bucket) \\
\hline Cooling coil tube temperature (3 places) & Surface-mounted type-T thermocouples \\
\hline Cooling coil air-side pressure drop & Pressure transducer \\
\hline
\end{tabular}

\subsection{References}

Henderson, H. and K. Rengarajan. 1996. A model to predict the latent capacity of air conditioners and heat pumps at part-load conditions with the constant fan operation. ASHRAE Transactions 102(1): 266274.

Henderson, H. 1998. The impact of part-load air conditioner operation on dehumidification performance: validating a latent capacity degradation model. Presented at ASHRAE's IAQ \& Energy 1998 Conference. New Orleans, LA. October.

Khattar, M.K., M.V. Swami and N. Ramanan. 1987. Another aspect of duty cycling: effects on indoor humidity. ASHRAE Transactions 93(1): 1678 - 1687.

Korte, C.M. and A.M. Jacobi. 1997. Condensate retention and shedding effects on air-side heat exchanger performance. Report \# ACRC TR-132. Urbana, IL: Air Conditioning and Refrigeration Center at the University of Illinois at Urbana-Champaign. 